Rev. Tadeusz Syczewski Katolicki Uniwersytet Lubelski Jana Pawła II

\title{
The Liturgical Feasts, Celebrations, Devotions, and Popular Piety of the Easter Season in the Roman Catholic Diocese of Drohiczyn, Poland
}

This work outlines in detail the annual rites, celebrations, and feasts that take place during the Easter season in the Roman Catholic Diocese of Drohiczyn, Poland. The entire Easter season is and continues to be observed as one great 50 -day feast. The popular piety of this season is characterized primarily by the ardent faith of the Polish people, which is expressed in their rich folklore, customs, and devotions that help them live the liturgy of the Church more deeply.

Key words: liturgy, popular piety, devotions, celebrations, feasts, Easter.

\section{Introduction}

Since the $4^{\text {th }}$ century, the Church has celebrated two events connected to the Resurrection of Christ: the Ascension of the Lord and the Pentencost. The Feast of the Ascension of the Lord commemorates Christ's royal enthronement and the glory that God prepared for his Son in Heaven. ${ }^{1}$ On Pentecost Sunday, Jesus Christ reveals Himself as the Precursor to the Holy Spirit. During the season of Easter, the Church also celebrates the feast days of St. Wojciech, Bishop and Martyr; the Most Holy Virgin Mary, Queen of Poland; St. Stanislaw, Bishop and Martyr; St. Mark the Evangelist; Sts. Philip and James,

See B. Nadolski, Liturgika Vol. II: Liturgia i Czas (Poznan: Pallotinum, 1991), 76 . 
the Apostles; St. Matthias; St. Andrew Boboli, priest; and the Visitation. The purpose of this article is to provide deeper theological insight into and a pastoral dimension of the feasts celebrated in the liturgy and through popular piety specifically during the Easter season in the Roman Catholic Diocese of Drohiczyn, Poland.

\section{The Feast of the Lord's Ascension}

The first reference to the Feast of the Ascension can be found in an entry from Etheria's diary, which she kept during her pilgrimage to the Holy Land in the $4^{\text {th }}$ century. At the beginning of the $5^{\text {th }}$ century, this feast was already known and celebrated everywhere. And texts containing the forms of the Mass for this feast appear in the Galarian and Gregorian sacramentaries under the title In ascensa Domini. In the Middle Ages, a dramatization took place, the remnants of which still remain today in the extinguishing of the Paschal candle after the Gospel on the Feast of the Ascension. In the $7^{\text {th }}$ century, the Church celebrated the vigil of this feast, and in the $11^{\text {th }}$ century, it dedicated an entire octave to it. Since the reforms of 1955, both of the aforementioned practices have been abolished. ${ }^{2}$

On the Feast of the Ascension, a procession would take place while people sang, "Through Your Holy Ascension." At the end of the procession, the celebrant would lift the cross and sing three times: "I am coming to my Father and your Father," and the choir would respond, "To our God and your God, alleluia." After the recitation of the Gospel, the Paschal candle would be blown out and returned with the Paschal cross on which hung a figure of the Resurrected Christ with a stole to the sacristy. ${ }^{3}$

According to current liturgical norms, however, the Paschal candle and the Paschal cross remain next to the altar until Pentecost Sunday, when the red stole is removed from the cross and the figure of the Risen Lord is transferred to the sacristy after Mass. The weekdays during the Ascension that precede Pentecost are special because these are the days when the Church and the faithful prepare for the coming of the Holy Spirit, the Consoler. On these days, a novena to the Holy Spirit is recited in the churches. This devotion is very well

See Ibid, 75-76.

See. W. Schenk, "Rok liturgiczny," Wprowadzenie do liturgii: praca zbiorowa (Poznan: Księgarnia Św. Wojciecha, 1967), 460-461. 
known among Catholic Christians. ${ }^{4}$ The words of this novena remind the faithful of the coming of the Holy Spirit. ${ }^{5}$ The faithful can receive Liturgy a partial indulgence by devotedly praying this novena. ${ }^{6}$

Novenas are often associated with devotions that take place in May or June. Before conferring the Eucharistic blessing, the celebrant recites special prayers. To enrich the novena, it is possible to sing the sequence "Come, Holy Spirit" or the hym "O Creator," either before or after the novena prayers are said. ${ }^{7}$

On August 22, 2001, Cardinal Józef Glemp, who was serving as the President of the Polish Bishops' Conference at the time, obtained permission from the Congregation for Divine Worship and the Discipline of the Sacraments to transfer the celebration of the Feast of the Ascension to the $7^{\text {th }}$ Sunday of Easter. Consequently, the feast was no longer a separate holy day of obligation. ${ }^{8}$ The provisions of the decree were binding beginning on the $1^{\text {st }}$ Sunday of Advent, meaning November $30,2003 .{ }^{9}$

In the past, priests usually blessed the inhabitants' fields after celebrating the Feast of the Ascension in the Church. During this rite, after Holy Mass was completed, the faithful carried crosses, banners, and reliquaries in procession while they sang religious songs in honor of the Blessed Mother and prayed the rosary or other prayers. The organist, priest, altar server, and the committee with the aspergillum and aspersorium followed. During this procession, the priest blessed the fields and meadows. At the entrance to each village, an altar was erected and decorated. This is where the priest and the faithful could pray and recite passages from the Gospel. Other inhabitants of a given place also joined in the procession as the priest blessed their cattle and property. During the entire procession, the faithful would sing songs and litanies to the Blessed Mother while they moved from one altar

4 Congregation for Divine Worship and the Discipline of the Sacraments, Directory on Popular Piety and the Liturgy: Principles and Guidelines (Vatican City, Italy: Libreria Editrice Vaticana, 2001), 155. Hereafter abbreviated as CDWDS, Directory.

See Ibid.

T. Syczewski, Ed., Kalendarz Liturgiczny Diecezji Drohiczyńskiej 2004 (Drohiczyn: 2005), 99; T. Syczewski, Ed., Stużba Boża w Diecezji Drohiczyńskiej (Drohiczyn: 1996), 203-208.

T. Syczewski, Ed., Stużba Boża, 203-208.

Congregation for Divine Worship and the Discipline of the Sacraments, "Dekret dotyczący świąt zniesionych w Polsce,” Anamnesis 9, no. 3 (2003): 34.

“Akta Konferencji Episkopatu Polski 2003," Anamnesis 9, no. 3 (2003): 18. 
to another until they had processed through the entire village. Today, the rite of blessing the fields looks completely different. According to this rite, the villagers gather at the entrance to the village next to the altar they have prepared especially for this feast. The priest, dressed in his liturgical vestments (usually wearing a surplice and an alb), starts praying according to the prescribed order. Usually the Holy Mass is celebrated at the very end, after the blessing of the fields. ${ }^{10}$

In spring, seeds are sown in the fields and gardens. On the Monday, Tuesday and Wednesday before the Ascension of the Lord, otherwise known as Cross Days, people pray special prayers asking the Lord to make the earth fruitful. On each of these three days, the faithful process around the church and pray for God's blessings and protection from all natural disasters, crop failures, and earthquakes. During this procession, the faithful follow the person who carries the cross, and they stop in four places. At the corner of the church cemetery and at the fourth stop, which is usually at the missionary cross, they pray the Litany of the Saints. These celebrations act as a reminder that the Church cares about man's affairs and believes that the prosperity and fertility of the earth depend not only on human wisdom or scientific knowledge, but most of all on God's blessings.

\section{Pentecost Sunday}

Pentecost Sunday completes the fifty days of the Easter Season. In some countries, Pentecost Sunday is called Red Easter (Pascha), while the Feast of the Resurrection of the Lord is called White Easter (Pascha). The date of the Feast of the Resurrection of the Lord coincides with the Jewish Feast of Passover. Fifty days after they passed through the Red Sea, the Israelites arrived to Mount Sinai, where they were given the Decalogue. During the time of Jesus, Passover was like a festival. Therefore, Christians have celebrated the Feast of Pentecost from the very beginning because it fell on a Sunday-the Sabbath. ${ }^{11}$

Since the $6^{\text {th }}$ century, the Feast of Pentecost was preceded by a vigil. Since the $7^{\text {th }}$ century, the feast was celebrated over the course of an octave, but this practice was abolished in 1960. On the Feast of Pentecost, milk and honey are blessed in the church. In addition, the sequence Veni Sanctae Spiritus is sung, which has been and remains

10 T. Syczewski and M. Łaziuk, eds., Obrzędy błogosławieństwa pól (Drohiczyn: Drohiczyńskie Wydawnictwo Diecezjalne, 1997); K. Matwiejuk and P.Paćkowski, eds., Obrzędy błogosławieństwa pól (Siedlce, 1997). 
the practice since 1570. Over the course of time, Pentecost Sunday became the Feast of the Holy Spirit. The liturgical vestments for this Liturgy feast are red. ${ }^{12}$ The known forms of Pentecost (Veni creator Spiritus and Veni, Sanctae Spiritus) or the short petitions (Emitte Spiritum tuum et creabuntur) help the faithful to call upon the Holy Spirit as they begin work, their studies, or in other areas of their lives. In addition, the third glorious mystery encourages the faithful to reflect on the descent of the Holy Spirit. ${ }^{13}$ The faithful readily pray these prayers in their daily lives, and the Holy Spirit is particularly worshiped at the moment of death because they believe that "the power of the Holy Spirit will revive them on the final day." 14

The Roman Missal of Paul VI from 1970 contains two forms of the Mass for the Feast of Pentecost. The purpose and spirit of this feast is made clear in the preface of the Descent of the Holy Spirit, which speaks of paschal joy, the foundation of which is the fulfillment of the work of salvation. ${ }^{15}$

The first Synod of the Diocese of Drohiczyn proclaimed: "The Feast of Pentecost is one of the greatest feasts in the Church. Its celebration, therefore, should be preceded by a novena to the Holy Spirit. On the actual feastday, parishes may organize vigils, vespers, and days of prayer. The proper solemn liturgy should take place on the eve of the feast. The faithful should be encouraged to cultivate pious habits associated with the Green Feasts. Since this celebration is the patronal feast of farmers and shepherds, it provides an opportunity to highlight the dignity of farming." 16

Penecost is truly a green feast as clearly evidenced in nature. Often the warm and floral feasts of farmers and shepherds occur in May or June. On these days, farmers would bring home young birch trees to place on the roofs of their homes, the cracks of the walls, or on fences, and in yards. The birch branches would often be woven into a hedge that was placed in front of homes, chapels, or roadside crosses. They also adorned the churches with them.

12 See B. Nadolski, Liturgika, 78.

13 CDWDS, Directory, 156.

14 Ibid.

15 "Prefacja o Zesłaniu Ducha Świętego, Nr. 27," Mszat rzymski dla diecezji polskich, $1^{\text {st }}$ Edition (Poznan: Pallottinun, 1986), 160*-161**

16 A. Dzięga and M. Łaziuk, eds., I Synod Diecezji Drohiczyńskiej, Statuty, Dokumenty wykonawcze (Drohiczyn: Drohiczyńskie Wydawnictwo Diecezjalne, 1997), 141. 
On this day, shepherds also celebrated their feast. In Diocese of Drohiczyn in the region along the Bug River it was a known custom to incense cattle and give palms to shepherds. Incensing the cattled was carried out in the following way: blessed wreaths were crushed and placed on hot coals. The mixture was then placed on a portable surface and carried around the cows as a way to protect the cows from misfortunes, wovles, and diseases. ${ }^{17}$ In addition, on Saturday evening before Pentecost, the faithful adorned the horns of their cows with special wreathes made from birth branches, or they tied the branches to the cows' heads. The woven figure of a man that looked like a knight was also placed on one of the cows, and two birch trees were arranged on either side of the gate through which the cattle passed. The path was also strewn with calamus, which was also placed on windowsills for their fragrance. The atmosphere of this night was unique, and everyone participated in the spirit of the feast. ${ }^{18}$

\section{The Feast of St. Wojciech, Bishop and Martyr (April 23)}

On April 23, the Church observes the Feast of St. Wojciech-bishop, martyr, and the main patron saint of Poland. ${ }^{19}$ Wojciech is a popular name of Slavic descent. It is made up of two parts: "woj-," meaning "warrior," as well as "-ciech," the derivative of which can also be found in the Polish words for "consolation" and "delight." ${ }^{20}$ Poland, the Czech Republic, and Hungry claim St. Wojciech as their patron. St. Wojciech was born in the Czech Republic and served as Bishop of Prague. He suffered a martyr's death, and his temporal remains are interred in Poland. St. Wojciech visited Hungry a few times, and he baptized St. Stephen of Hungary. ${ }^{21}$

St. Wojciech was born around the year 956 A.D. in Libice, Bohemia, into the powerful Slavnik clan that lived an estuary on the Elbe River. Educated in Magdeburg, St. Wojciech was only 25 year old and a subdeacon when he returned to Bohemia. He was subsequently ordained to the diaconate and priesthood in Prague. In 983, after the death of

17 This data was obtained through the author's own empirical studies.

18 This data was obtained through the author's own empirical studies.

19 T. Syczewski, ed., Kalendarz Liturgiczny Diecezji Drohiczyńskiej 2005, 92-93.

20 See H. Fros and F. Sowa, Twoje imię (Cracow: Wydawnictwo Apostolstwa Modlitwy, 1982), 536.

$21 \quad$ See W. Zaleski, Rok kościelny (Warsaw: Wydawnictwo Spółdzielcze, 1989), 272; S. Rospond, Święty Wojciech (Cracow: Wydawnictwo Instytutu Teologicznego Księzy Mizjonarzy, 1988), 3. 
Bishop Dietmar, St. Wojciech was ordained bishop of Prague. Due to various conflicts and problems, this position proved to be very difficult. Liturgy Unable to cope with these difficulties, St. Wojciech went to Rome to seek Pope John XV's advice. With the Pope's consent, St. Wojciech took up residence at the Benedictine monastery at Monte Casino and then at St. Boniface on Aventine, where he received the Benedictine habit. At the request of the faithful, St. Wojciech gave into the Pope's wishes and returned to Prague in 922, where he once again took up church matters. Due to the conflicts among his family members, St. Wojciech had to leave Prague once again in 995 and go to Rome. Soon after, his hometown was destroyed. his brothers were murdered, and it was not longer safe for him to return home.

While in Italy, St. Wojciech met Emperor Otto III and began to consider missionary work. To this end, he moved to Poland where, in 966, Boleslaw Chrobry warmly welcomed him. St. Wojciech then went to Prussia with his brother Radim and a Benedictine priest. Here, he suffered a martyr's death by arrows. Once he was dead, St. Wojciech's head was cut off and buried on April 23, 997. Boleslaw Chrobry purchased St. Wojciech's martyred remains and reverently interred them in the Cathedral in Gniezno. Pope Sylvester II canonized St. Wojciech on December 2, 999. ${ }^{22}$ The cult of St. Wojciech spread in Poland from the very moment of his death.

The mass for the Saint Wojciech has its own form and preface. ${ }^{23}$

In the Diocese of Drohiczyn there are many known proverbs pertaining to St. Wojciech. Among them, the most common is: "If the crow is alive on St. Wojciech's feast, the grain abundantly thrives." The Feast of St. Wojciech was an important day for farmers. On this day, they did many "magical" things to ensure the safety of their cattle. For example, they drove their livestock over a threshold, under which was hidden a scythe, scissors, a sickle, an axe, and sometimes a broom. On this day, the cattle were also incensed with smoke from the burning herbs consecrated to the Virgin Mary or from palms and then sprinkled with holy water. Wreathes made of blessed herbs were hung from the animals' horns. Cattle were also struck with blessed palms while the sign of the cross was made over them. Sometimes the animals would be fed

22 See H. Fros and F. Sowa, Twoje imię, 536-537; H. Hover, Żywoty świętych Pańskich (Olsztyn: Warmińskie Wydawnictwo Diecezjalne, 1983), 462; P. Parsch, Rok liturgiczny, Vol. 2 (Poznan: Wydawnictwo Pallotinum, 1956), 396; S. Rospond, Święty Wojciech, 6; V. Schauber, H. M. Schindler, Ilustrowany leksykon świętych (Kielce: Wydawnictwo Jedność, 2002), 771; W. Zaleski, Rok kościelny, 272-281. 
a lump of salt or given a piece of blessed bread from Holy Saturday. ${ }^{24}$ In addition, when they went out into the fields to plow after winter, farmers sprinked holy water on their plows so that moles would not destroy their land and, consequently, its yield.

\section{The Feast of the Most Holy Virgin Mary, Queen of Poland (May 3)}

The Church celebrates the Feast of the Most Holy Virgin Mary, Queen of Poland, on May 3. This feast was introduced in Poland in 1959 at the Polish bishops' special request. ${ }^{25}$ Jan Długosz named Mary "The Lady and Queen of the world and us." On April 1, 1656, King Kazimierz entrusted the entire country of Poland to the Mother of God's care by solemnly proclaiming her Queen of Poland from the Lviv cathedral, saying: "Today I receive you as my Patron and as the Queen of my country." ${ }^{26}$ In 1920, Pope Benedict XV established May 3 as the Feast of the Queen of Poland in order to emphasize the indissoluble unity between this feast and the four-year sejm as well as with the adoption of the Constitution of May 3. Pope St. Pius XI gave this feast its own Mass as well as its own office of readings. On August 3, 1962, Pope St. John XXIII proclaimed the Most Holy Virgin Mary, Queen of Poland, the main patron of the entire nation. ${ }^{27}$

During the preparations for the 1000-year anniversary of the existence of Poland (966-1966), at the invitation of the Primate of Poland Cardinal Stefan Wyszyński, the entire Polish nation once again entrusted itself to the care of the Most Holy Virgin Mary during the "Great Novena." All of the dioceses in Poland participated in this event, during which each believer entrusted himself to Mary. For 20 years, the traveling image of Our Lady of Częstochowa visited all of the parishes and shrines in Poland, which demonstrated the close connection between the people of Poland and their Queen. At each parish, devotions took place and parishioners sang a special song in honor of Our Lady of Częstochowa. ${ }^{28}$

24 SeeE.Ferenc-Szydełkowa, Rokkościelny a polskie tradycje (Poznan: Księgarnia Świętego Wojciecha, 1988), 162.

See B. Nadolski, Liturgika, 142.

Ibid, 141-142.

See W. Zaleski, Rok kościelny, 296-297; P. Parsch, Rok liturgiczny, 413; S. Wyrwas, "Dzieje kultu Najświętszej Maryi Panny Królowej Polski," Studia z dziejów liturgii w Polsce, Vol. 2, eds. M. Rechowicz and W. Schenk (Lublin: 1976), 437.

See W. Zaleski, Rok kościelny, 297. 
In the Diocese of Drohiczyn, there are six shrines: the chapel Bielany, Czeremcha, Niemyje Nowe, Ostrówek, the chapel Samułki, and the Liturgy chapel Wałki, which are dedicated to the honor of the Most Holy Virgin Mary, Queen of Poland. On May 3, every parish in the Diocese of Drohiczyn renews the Millenial Act of entrusting Poland to the motheral care of Mary, the Mother of the Church, so that the Church of Christ may be free. ${ }^{29}$ This celebration has its own form and preface. ${ }^{30}$

\section{The Feast of St. Stanisław, Bishop and Martyr (May 8)}

The Feast of St. Stanisław, Bishop, Martyr, and main patron of Poland, is celebrated on May $8 .{ }^{31}$ While the exact date of St. Stanisław's birth is unknown, historians believe that he was born sometime between 1030 and 1035 in Szczepanów. St. Stanisław came from the Turzyn family, and he most likely studied initially in Tyniec at a Benedictine monastery and then abroad, probably in Liege or Paris. He was ordained to the priesthood in 1060. In 1072, he became bishop of Cracow and cared primarily for the poor, widows, and orphans. For unknown reasons, St. Stanisław entered into a conflict with King Bolesław Śmiały. On April 11, 1079, St. Stanisław was murdered in the church in Skałka either by King Bolesław's order (or by the king himself) while he was celebrating the Holy Mass. On September 17, 1253 , Innocent VI canonized St. Stanisław in the Church of St. Francis of Assisi. In honor of St. Stanisław's merits and as a result of many miracles he performed, the hym "Gaude Mater Polonia" was composed. This hym is currently sung in various forms during patriotic celebrations and at the beginning of the academic year in all Polish institutions of higher education. ${ }^{32}$

29 T. Syczewski, ed., Kalendarz Liturgiczny Diecezji Drohiczyńskiej 2004 (Drohiczyn, 2003), 214.

30 Mszat Rzymski dla Diecezji Polskich, 52.

31 T. Syczewski, ed., Kalendarz Liturgiczny Diecezji Drohiczyńskiej 2004, 101.

32 SeeW.Zaleski, Rokkościelny,319-325; S. Sułkowski and Z. Wiktorzak, "Stanisław ze Szczepanowa," Hagiografia polska, Vol. 2 (Poznan, 1972), 421-423; B. Przybyszewski, "Święty Stanisław Biskup,” Polscy święci, ed. J. R. Bar (Warsaw: 1983), 11-33; S. Bełch, Święty Stanisław biskup męczennik (London: 1977), 210-211; F. Koneczny, Święci w dziejach narodu polskiego (Miejsce Piastowe: Wydawnictwo Miejsce Piastowe, 1937), 60-61; W. Schenk, Kult liturgiczny św. Stanisława biskupa na Śląsku w świetle średniowiecznych rękopisów liturgicznych (Lublin: Twoarzystwo Naukowe Katolickiego Uniwersytetu Lubelskiego, 1958), 16. 
In the Diocese of Drohiczyn, there are 10 churches dedicated to St. Stanisław, each located in: Hajnówka, Knychówek, Milejczyce, Narew, Niemirów, Pobikry, Sarnaki, Skrzeszew, Stoczek Węgrowski, and Topczewo. ${ }^{33}$ Very celebratory indulgences connected with St. Stanisław are sought and granted in the diocese's parishes. During these celebrations, preachers are invited to speak, and it is possible for the faithful to participate in the Sacrament of Penance and Reconciliation. According to the popular piety, sayings regarding a good harvest and farmers' wealth that are connected with St. Stanislaw have been passed down: "On St. Stanisław's feast the rye will stand straight and tall," ${ }^{44}$ or "After St. Stanisław's feast, the ox will lie down on the grass." 35,36 The faithful trust this saint and believe in his great help.

The Feast of St. Stanisław has its own form and preface. ${ }^{37}$

\section{Feast of St. Mark the Evangelist (April 25)}

The Church observes the Fast of St. Mark the Evangelist on April 25. St. Mark was the author of the second Gospel. It is likely that his mother owned the Upper Room where Jesus shared the Last Supper with his Apostles. When Jesus died on the cross, Mark was only a youth. For this reason, the passage in Scripture, "Now a young man followed [Jesus] wearing nothing but a linen cloth about his body" (Mk. 14: 50-52) as they took Jesus from the Garden of Gethsemane refers to Mark. Mark accompanied St. Barnabas, his cousin, as well as St. Paul to Antioch and then to Cyprus. He was St. Paul and St. Peter's protégé. According to tradition, St. Peter sent St. Mark to Egypt where he died a martyr's death; however, there are no records of this event. The relics of St. Mark the Evangelist were translated to Venice, where a cathedral was built in his honor. ${ }^{38}$

T. Syczewski, ed., Kalendarz Liturgiczny Diecezji Drohiczyńskiej 2004, 101.

Translators explanation: At the beginning of May, the rye, which was planted in the autumn, has grown and stands tall.

Translator's explanation: Later in May and into June, the grass has begun and continues to grow, providing a soft spot on the ground where the ox can lie down to rest.

See C. Złotkowski, Zwyczaje wsi Podlasia w połowie XX wieku (Biała Podlaska: 2006), 131.

Mszat Rzymski dla Diecezji Polskich, 57.

See H. Hoever, Żywoty, 148-149; W. Zaleski, Święci, 204. 
St. Mark is the patron saint of writers, masons, basketball players, and glaziers. In some regions of Poland, he is the patron of wheat, Liturgy vegetables, and spring sowing. ${ }^{39}$

The Feast of St. Mark has its own form. ${ }^{40}$ It falls during the height of spring, when the fields are green. Since the Middle Ages, people have recited prayers on this feastday to ask for God's blessing so that the harvests and the fruit of the trees might be abundant. This day is called "The Day of Prayer for the Harvests" or "The Greater Litanies" because the Cross Days that occur before the Feast of the Ascension of the Lord are called the "Lesser Litanies," since they were introduced into the liturgy of the Church later. ${ }^{41}$ The Polish name for St. Mark's feastday- "Cross Days"-derives comes from the processions that proceed along the roadside from one cross to another. St. Mark is also honored as the patron of good weather. ${ }^{42}$ On his feastday, farmers refrain from working in the field in order to avoid making St. Mark angry and expressing this anger through lightning that could burn the crops. On this day, oxen are adorned in flowers, herbs, and branches.

"Cross Days," which are recited to St. Mark, are "public prayers for the fruitfulness of the earth and occur once a year after the $5^{\text {th }}$ Sunday of Easter, on the Monday, Tuesday, and Wednesday before the Feast of the Ascension." In the Middle Ages, there were many different incurable diseases, plagues, leprosy, etc. Therefore, people erected roadway crosses to request the saints' protection from these maladies.

According to popular piety, St. Mark is also the patron of gardeners. He is particularly honored as the patron of the harvest in the field and of gardens. The happiest and best days to sow seeds are Monday (poniedziatek), Friday (piatek), and Saturday (sobota) because these days of the week do not contain the letter " $r$ " in Polish, which is a letter associated with the crow (wrona) that attacks cornfields and eats the grain. Similarly, housekeepers worked on Wednesday (środa) and Thursday (czwartek), since these days contain a letter " $r$ " in Polish, and, as previously stated, they were afraid that the crows would eat the freshly sown grain if they worked in the fields. ${ }^{43}$ The Feast of St. Mark is the last day that the homemaker can sow peas and flax. In addition, there was such a custom wherein Easter eggs were added to the flaxseed sack so that the heads of the flax seeds grew large like

39 See W. Zaleski, Rok kościelny, 283-284.

$40 \quad$ Mszał Rzymski dla Diecezji Polskich, 44-45.

$41 \quad$ See W. Zaleski, Rok kościelny, 284.

42 See H. Fros and F. Sowa, Twoje imię, 335.

43 This data was obtained through the author's own empirical studies. 
eggs. Farmers always began the workd of sowinging seeds with the Sign of the Cross.

St. Mark's Day is treated like Cross Days. On this day, processions with the cross take place around the church, and the procession stops at the same four stations. At each station, a different intention is mentioned (for example, for a fruitful harvest and for preservation from natural disasters such as lightning and droughts). During these prayers, the faithful sing the Litany of the Saints.

\section{The Feast of Sts. Philip and James the Apostles (May 6)}

The Feast of Sts. Philip and James was formerly observed on May 1. However, Pope Pius XII changed the feastday to May 11. Currently, this feast is celebrated on May 3 throughout the world. In Poland, however, the Feast of Sts. Philip and James the Apostles is celebrated on May $6 .{ }^{44}$ Philip came from Bethsaida, the same city as Andrew and Peter. Philip was a fervent witness to Jesus Christ, and he was present when Jesus miraculously multiplied the loaves and fishes (cf. John 6: 1-5). Philip enjoyed Jesus' special trust because some people asked him to help them meet Jesus (cf. John 12:21-22). The Apostle Philip announced the Gospel message about the Kingdom of Heaven after the Ascension of Christ in Phrygia, Asia Minor. It is highly likely that there he also suffered a martyr's death on a cross. ${ }^{45}$

Tradition considers James the first bishop of Jerusalem. In the year 62 A.D., St. James the Younger was stoned to death. Immediately after his death, he was honored by the people and among the Jews. At present, his relics are interred in the Basilica of Sts. Philip and James in Rome. In Rome there is also a church dedicated to St. James. The hand of St. James the Apostle can be found in a beautiful reliquary in the Cathedral in Genoa. ${ }^{46}$

The Feast of Sts. Philip and James has its own liturgical form. ${ }^{47}$

\footnotetext{
${ }_{44}$ T. Syczewski, ed., Kalendarz Liturgiczny Diecezji Drohiczyńskiej 2005 (Drohiczyn, 2004), 100.

45 See W. Zaleski, Rok kościelny, 311-312.

$46 \quad$ See Ibid, 313-314.

$47 \quad$ Mszat Rzymski dla Diecezji Polskich, 54-55.
} 


\section{The Feast of St Matthias (May 14)}

The Feast of St. Matthias the Apostle is celebrated on May $14 .{ }^{48} \mathrm{St}$. Matthias was of Jewish descent, one of the first followers of Christ, and chosen to replace Judas (cf. Acts 1:15). St. Matthias introduced the practices of abstinence and bodily mortification into the life of the church and monastic life. After preaching the Gospel message in Judea and Ethiopia, St. Matthias was stoned to death as an enemy and betrayer of the Jewish nation. Clement of Alexandria claims that Matthias died a natural death. ${ }^{49}$

Iconography of St. Matthias most often presents him with an axe, since he was killed either by stoning, an axe, or a spear. He is considered the patron of carpenters and craftsmen. His feast was celebrated on February 24 and 25, depending on whether or not leap year occurs. However, the reformed liturgical calendar transferred his feat to May $14 . .^{50}$

The Feast of St. Matthias has its own form. ${ }^{51}$

\section{The Feast of St. Andrew Boboli, Priest (May 16)}

St. Andrew Boboli was born around the year 1591. On July 31, 1611, he entered the Jesuits in Vilnius. From 1613 to 1616, St. Andrew studied philosophy at the Vilnius Academy and in Brunsberg and Pułtusk. From 1618 to 1620, he returned to study theology in Vilnius. In 1622, he was ordained to the priesthood. As a priest, he was earnest, dedicated, and had great missionary zeal. On May 1, 1657, the Cossaks murdered St. Andrew in Janów Poleski. Pope Pius IX beatified St. Andrew on November 20,1853, and Pope Pius XI canonized him on April 17, 1938. On May 16, 2002, he was declaired the fourth patron of Poland. ${ }^{52}$

In the Diocese of Drohiczyn, there are three churches dedicated to St. Andrew Boboli, and they are located in Budziska, Czekanów, and Siemiatycze. There is also one chapel dedicated to him in Liza Stara. Devotion to St. Andrew in the Diocese of Drohiczyn is widespread among the faithful.

T. Syczewski, ed., Kalendarz Liturgiczny diecezji drohiczyńskiej 2005, 103.

W. Zaleski, Rok kościelny, 330-331; H. Hoever, Żywoty, 171; K. Radoński, Święci i błogosławieni kościoła katolickiego (Warsaw, Poznan, Lublin: 1947), 302.

Mszat Rzymski dla Diecezji Polskich, 60; see W. Zaleski, Rok kościelny, 331. Mszat Rzymski dla Diecezji Polskich, 60-61.

P. V. Schauber and H. M. Schindler, Ilustrowany leksykon świętych, $2^{\text {nd }}$ Edition (Kielce: 2003), 30. 
The Feast of St. Andrew Boboli has its own form. ${ }^{53}$

\section{The Feast of the Visitation (May 31)}

In 1263, St. Bonaventure introduced the Feast of the Visitation of the Blessed Virgin Mary into his religious order. In 1389, Pope Boniface IX promulgated this feast throughout the entire Church as a means of beseeching the faithful to be united in the church of Christ. The Council of Basel approved this feast, and Pope Pius IX elevated it to the rank of a second-class feast in 1850. Until 1969, or the reform of the liturgical calendar, the feasday was observed on July 2. After the reform, it was moved to the last day of May. The Gospel of Luke describes the Visitation (cf. Lk. 1:39-56), the most wonderful and lasting remembrance of which is the beautiful hym of the Magnificat that is recited every day in the Liturgy of the Hours. ${ }^{54}$ The theological content of this feast highlights the truth that the New Covenant is the law of grace through which the Holy Spirit works. In the Magnificat, Mary expresses her faith, praise, and amazement at the workings of grace. In this way, Mary wishes to encourage the entire Church to honor God, who has done great and wonderful things for all mankind. The Feast of the Visitation also serves as reminder that God is present among his people Israel. ${ }^{55}$

This feastday has its own form. ${ }^{56}$

According to the Polish tradition, the Feast of the Visitation is called "Our Lady of the Berries" because strawberries and currants can be found ripe in the forest at this time of year. Until 1969, the Feast of the Visitation was observed on July 2. According to one legend, while Mary was walking to visit her cousin Elizabeth, she stopped along the way and picked berries. For this reason, some Poles do not eat any cherries, raspberries, strawberries, currants, gooseberries, or other fruits found in the forest on this day so that the Mother of God will not be lacking in anything on her feastday. ${ }^{57}$ In the Diocese of Drohiczyn, there is a particular devotion to Our Lady of the Berries. Her image, which was originally located in the parish in Grodzisk K. Siemiatycz, was transferred to Ziołowy Zakątek in Koryciny.

\footnotetext{
53 Mszat Rzymski dla Diecezji Polskich, 61-62.

54 W.Zaleski, Rok kościelny, 353-355; Liturgia Godzin, Vol 2 (Poznan: Pallottinum, 1984), 1464-1474.

55 B. Nadolski, Liturgika, 136.

56 Mszat Rzymski dla Diecezji Polskich, 71-72.

57 E. Ferenc-Szydełkowa, Rok kościelny, 194-195.
} 


\section{Conclusion}

The Easter season in Poland has a rich variety of customs and folk rituals, which, although not strictly part of the liturgy, are inspired by the liturgy; correspond with the liturgical year; preserve the liturgy's spirit, canonical norms, and rhythm; and direct the Christian people to the liturgy.$^{58}$ In addition, these customs and rituals are an expression of the people's deep faith and attachment to the Church. Many of these customs are celebrated with the permission of the Holy See or the bishops and, therefore, are in accord with the spirit of the Church and fundamentally express divine revelation. ${ }^{59}$ Popular piety and custums are always celebrated and practiced "in accordance with the customs or canonically approved books." 60 These devotions are organized according to the sacred liturgy, because they flow from it and lead the faithful to it. ${ }^{61}$

\section{UROCZYSTOŚCI I ŚWIĘTA OBCHODZONE W OKRESIE WIELKANOCNYM W LITURGII I POBOŻNOŚCI LUDOWEJ W KOŚCIELE ŁACIŃSKIM NA TERENIE DIECEZJI DROHICZYŃSKIEJ}

Niniejsze opracowanie szczegółowo ukazuje doroczną obrzędowość okresu wielkanocnego w przypadających na ten okres uroczystościach i świętach. Cały ten okres był i jest obchodzony jako jedno wielkie święto, jako czas Pięćdziesiątnicy. Pobożność ludowa tego okresu charakteryzuje się przede wszystkim głęboką wiarą wyrażaną w bogatej oprawie folklorystyczno-zwyczajowej. Diecezja drohiczyńska jest bardzo bogata w pobożność ludową tego okresu. Nabożeństwa te cieszą się wśród wiernych szczególnym uznaniem. Wiele z tych zwyczajów zrodziło się z potrzeby serca wiernych i dopomaga w głębszym przeżywaniu liturgii Kościoła.

Słowa kluczowe: liturgia, pobożność ludowa, uroczystość, święta, Wielkanoc.

\section{Bibliography:}

1. “Akta Konferencji Episkopatu Polski 2003.” In Anamnesis 9, no. 3 (2003): 18.

58 See Pope Paul VI, Constitution on the Sacred Liturgy: Sacrosanctum Concilium (Vatican City, Italy: Libreria Editrice Vaticana, 1963), 13. Hereafter abbreviated as $S C$.

59 CDWDS, Directory, 17.

$60 S C, 13$.

61 Ibid. 
2. Bełch, S. Święty Stanisław biskup męczennik. London: 1977.

3. Biblia Tysiaclecia: Pismo Święte Starego i Nowego Testamentu. $3^{\text {rd }}$ Edition. Poznan: Pallottiunum, 1980.

4. Congregation for Divine Worship and the Discipline of the Sacraments. "Dekret dotyczacy świat zniesionych w Polsce," Anamnesis 9, no. 3(2003), nr. 34, 18 .

5. Congregation for Divine Worship and the Discipline of the Sacraments. Directory on Popular Piety and the Liturgy: Principles and Guidelines. Vatican City, Italy: Libreria Editrice Vaticana, 2001.

6. Dzięga, A., and M. Łaziuk, Eds. I Synod Diecezji Drohiczyńskiej, Statuty, Dokumenty wykonawcze. Drohiczyn: Drohiczyńskie Wydawnictwo Diecezjalne, 1997, 141.

7. Ferenc-Szydełkowa, E. Rok kościelny a polskie tradycje. Poznan: Księgarnia Świętego Wojciecha, 1988.

8. Fros, H., and F. Sowa. Twoje imię. Cracow: Wydawnictwo Apostolstwa Modlitwy, 1982.

9. Hover, H. Żywoty świętych Pańskich. Olsztyn: Warmińskie Wydawnictwo Diecezjalne, 1983.

10. Koneczny, F. Święci w dziejach narodu polskiego. Miejsce Piastowe: Wydawnictwo Miejsce Piastowe, 1937.

11. Liturgia Godzin. Vol. II. Poznan: Pallottinum, 1984.

12. Matwiejuk, K. and P. Paćkowski, Eds. Obrzędy błogosławieństwa pól. Siedlce, 1997.

13. Mszat rzymski dla diecezji polskich, $1^{\text {st }}$ Edition. Poznan: Pallottinun, 1986.

14. Nadolski, B. Liturgika Vol II: Liturgia i Czas. Poznan: Pallotinum, 1991.

15. Parsch, P. Rok liturgiczny, Vol. 2, Poznań 1956.

16. Pope Paul VI. Constitution on the Sacred Liturgy: Sacrosanctum Concilium. Vatican City, Italy: Libreria Editrice Vaticana, 1963.

17. Przybyszewski, B. "Święty Stanisław Biskup." Polscy święci, Edited by J. R. Bar. Warsaw: 1983.

18. Radoński, K. Święci i błogosławieni, kościoła katolickiego. Warsaw, Poznan, Lublin: 1947.

19. Rospond, S. Święty Wojciech. Cracow: Wydawnictwo Instytutu Teologicznego Księzy Mizjonarzy, 1988.

20. Schauber, V., and H. M. Schindler. Ilustrowany leksykon świętych. Kielce: Wydawnictwa Jedność, 2002.

21. Schauber, P. V., and H. M. Schindler. Ilustrowany leksykon świętych. $2^{\text {nd }}$ Edition. Kielce: 2003.

22. Schenk, W. Kult liturgiczny św. Stanisława biskupa na Śląsku w świetle średniowiecznych rękopisów liturgicznych. Lublin: Twoarzystwo Naukowe Katolickiego Uniwersytetu Lubelskiego, 1958.

23. Schenk, W. "Rok liturgiczny." In Wprowadzenie do liturgii: praca zbiorowa. Poznan: Księgarnia Sw. Wojciecha, 1967, 460-461.

24. Sułkowski, S., and Z. Wiktorzak. "Stanisław ze Szczepanowa." Hagiografia polska, Vol. 2. Poznan: 1972, 421-423.

25. Syczewski, T., Ed. Kalendarz Liturgiczny Diecezji Drohiczyńskiej 2004. Drohiczyn: 2003. 
26. Syczewski, T., Ed. Kalendarz Liturgiczny Diecezji Drohiczyńskiej 2005. Drohiczyn: 2004.

27. Syczewski, T., and M. Łaziuk, Eds. Obrzędy błogosławieństwa pól. Drohiczyn: Drohiczyńskie Wydawnictwo Diecezjalne, 1997.

28. Syczewski, T., Ed. Stużba Boża w Diecezji Drohiczyńskiej. Drohiczyn: 1996.

29. Wyrwas, S. "Dzieje kultu Najświętszej Maryi Panny Królowej Polski." Studia z dziejów liturgii w Polsce, Vol. 2. Edited by M. Rechowicz and W. Schenk. Lublin: 1976, 437

30. Zaleski, W. Rok kościelny. Warsaw: Wydawnictwo Spółdzielcze, 1989.

31. Złotkowski, C. Zwyczaje wsi Podlasia w połowie XX wieku. Biala Podlaska: 2006. 